\title{
Rebuilding the community and the church post-COVID-19
}

\author{
Pieter Verster \\ Research fellow \\ Department of Practical and Missional Theology \\ Faculty of Theology \\ University of the Free State, South Africa \\ E-mail: versterp@ufs.ac.za \\ Doi: https://doi.org/10.46222/pharosjot.102.043
}

\begin{abstract}
The catastrophic destructions of the Temple in Jewish history led to different reactions. Although they left a serious mark on all of Israel's future endeavours and the prophets warned the people of the coming disasters, they also proclaimed hope, even after the destruction. Some Jews reacted to it by forming close-knit communities and their commitment to the Torah. It remained a serious challenge to their faith and community life. They carefully studied the prophets to understand the implications of the destructions of the temples. Christians explained that Jesus had to be honoured as Lord after the destruction of the Temple. In the Gospels, Jesus foretold the terrible situation of the demise of the Temple and that his body would be the new Temple. New life is possible in Him and in the coming of the Kingdom. Some exegetes link the cursing of the fig tree by Jesus to the destruction of the temple, but others see it as a general warning to the Jewish people to honour God. It is also very important that the resurrection of Jesus is regarded as the rebuilding of the new temple in his body. After the COVID-19 pandemic, believers as servants of the Lord have to build up the church and empower the community again. This should be done in respect of Jesus the crucified and resurrected Lord. The church has a huge task in this regard, not only by proclaiming Jesus as our only comfort in life and death, but also in the commitment to the building up of the community post-Covid-19. This should be accomplished by humbling and fully following Jesus.
\end{abstract}

Keywords: COVID-19, destruction of the Temple, Jesus as Lord, church, new life

\section{Introduction}

A new situation will emerge after the destruction, after the COVID-19 pandemic. The question is: How will the church respond to the situation post-COVID-19? What will be done and what will be the future of the church after this pandemic? How will the church address the challenges in the community post-COVID-19? COVID-19 is a dreadful disease that led to millions of deaths, massive financial loss, and other community challenges. The response of the Jewish community after 587-586BCE and 70CE and of the Christian church after the destruction of the Temple in $70 \mathrm{CE}$ is important and can be helpful in our understanding of how to address the issues at hand.

\section{The destruction of the Temple of Jerusalem}

Biblical times saw catastrophic destructions in Jewish history. According to Stone (1981:195ff.), the destructions of the Temple by Nebuchadnezzar in 587-586BCE, by Antiochus IV Epiphanes in 169-168BCE, and by Pompey in 63BCE, as well as the total destruction of the Temple by Titus in 70CE were total disasters. Stone mentions that the total destruction of the Temple in 
70CE was a dreadful event in Judaism. The Temple had very important implications for the faith of the Israelites. According to Bright (1977:327), it seems that the destruction of Israel was precipitated by incompetence and political chaos and that the kings and rulers of Israel were bent on this destruction themselves. Harrison (1971:250) refers to the "horrors" of the captivity after the destruction of the Temple. Bruce (1969:92) describes the utter disaster of the last days of the Temple.

De Silva (2004:75) explains how the Temple and the sacrifices at the Temple related to all aspects of their lives. The Torah and the Temple were deeply linked. God met his people at the Temple. Land and covenantal relations were also entrenched in their faith at the Temple. They experienced the goodness of God as well as His judgement at the Temple. To live with God was the foremost implication of the Temple, where one could come near to God and renew the covenantal relation (see also 1 Kings 8 ).

The total destruction of the Temple had serious implications for the faith of the Israelites. The description of the destruction of the first temple is emphatic. One can refer to biblical texts such as 2 Kings 25:8-11 in this regard:

8 On the seventh day of the fifth month, in the nineteenth year of Nebuchadnezzar king of Babylon, Nebuzaradan commander of the imperial guard, an official of the king of Babylon, came to Jerusalem. ${ }^{9} \mathrm{He}$ set fire to the temple of the LORD, the royal palace and all the houses of Jerusalem. Every important building he burned down. ${ }^{10}$ The whole Babylonian army under the commander of the imperial guard broke down the walls around Jerusalem. ${ }^{11}$ Nebuzaradan the commander of the guard carried into exile the people who remained in the city, along with the rest of the populace and those who had deserted to the king of Babylon. ${ }^{12}$ But the commander left behind some of the poorest people of the land to work the vineyards and fields.

Volkmar (2003:s.p. Logos) explains the total destruction. However, many people were spared, thus leading to the possibility of a new future. Patterson and Hermann (1988:s.p. Logos) show that Nebuzaradan saw to the total destruction and burning of Jerusalem. They explain the extent of the intensive calamity: "Then they deported certain valued elements of the citizenry of Jerusalem and the populace of the surrounding countryside, some of whom apparently willingly defected to the invaders (v. 11; cf. Jeremiah. 39:9; 52:15)."

Hobbs (1985:s.p. Logos.) opines:

In the narrative that follows a similar precision is to be noted in the systematic elimination of any vestige of order and symbol. Sacred place (land, city, temple) is violated. Sacred persons (king, priests, officials) are killed, maimed, or exiled. The actions are deliberate, without comment, and have an air of finality about the* $m$. Here is dénouement.

2 Chronicles 36:15ff.:

${ }^{15}$ The LORD, the God of their ancestors, sent word to them through his messengers again and again, because he had pity on his people and on his dwelling place. ${ }^{16}$ But they mocked God's messengers, despised his words and scoffed at his prophets until the wrath of the LORD was 
aroused against his people and there was no remedy. ${ }^{17} \mathrm{He}$ brought up against them the king of the Babylonians, ${ }^{[0]}$ who killed their young men with the sword in the sanctuary, and did not spare young men or young women, the elderly or the infirm. God gave them all into the hands of Nebuchadnezzar. ${ }^{18} \mathrm{He}$ carried to Babylon all the articles from the temple of God, both large and small, and the treasures of the LORD's temple and the treasures of the king and his officials. ${ }^{19}$ They set fire to God's temple and broke down the wall of Jerusalem; they burned all the palaces and destroyed everything of value there.

Payne (1988:s.p. Logos) refers to the fact that, although Chronicles also depicts the destruction, there is another theme. God judged Israel sternly, but there is also hope. God is full of grace: "nation refined by its trials could more adequately celebrate the Lord's continuing providence together with his anticipated triumph in the messianic kingdom that yet must come into being."

Dillard (1987:s.p. Logos) opines that, although the destruction of the Temple led to much distress, there was the anticipation of renewal in the offspring of David. God's grace and righteousness are also present and should be expected.

Regeneration is also evident in Jeremiah 33:6-7:

6 'Nevertheless, I will bring health and healing to it; I will heal my people and will let them enjoy abundant peace and security. ${ }^{7}$ I will bring Judah and Israel back from captivity $\underline{[}]$ and will rebuild them as they were before. ${ }^{8}$ I will cleanse them from all the sin they have committed against me and will forgive all their sins of rebellion against me. ${ }^{9}$ Then this city will bring me renown, joy, praise and honor before all nations on earth that hear of all the good things I do for it; and they will be in awe and will tremble at the abundant prosperity and peace I provide for it.'

Holladay (1989:s.p. Logos) explains hope for the future: "[l]t is not only the assurance of a future Davidic king that sustains this section of the community but also the affirmation of the future status of the Levitical priests as well." Weiser (1972:220) explains that Jeremiah proclaims judgement and regeneration after conversion. He stood on God's side but also loved the people to whom he proclaimed hope.

Daniel 12:1 ff.:

${ }^{12}$ At that time Michael, the great prince who protects your people, will arise. There will be a time of distress such as has not happened from the beginning of nations until then. But at that time your people - everyone whose name is found written in the book - will be delivered.

The previous disasters and the final destruction in 70CE raised the question: How should one regard these calamities? Stone (1981:196) refers to the issue of theodicy or why God allows the appearance of malevolence, thereby resolving the question of the problematic of evil. What did really happen and how should one understand what happened regarding the destruction of the Jewish Temple? The Jews often concluded that God punished them, that there was an eschatological element of total destruction, and that there was also the issue of how to ever rebuild the Temple and how a new situation can arise. 
Many of the post-exilic apocalyptic sources, like the books of the Maccabees refer to the destruction of the Temple that ultimately led to a totally new way of thinking about God. Stone (1981:200) states:

All the formulations of the problem arising from the destruction mentioned so far imply an acceptance of God's justice in allowing it to happen. The terrible fate of the city and its holy place, cause anguish and distress. Writers lament, weep, cry out their pain over this terrible calamity. Yet, the righteousness of God's action is not questioned.

The initial Temple in Jerusalem, built by Solomon, was destroyed by the Babylonians in 587BCE. The second temple was built on the same site in 515BCE.

As for the destruction of the second Temple in $70 \mathrm{CE}$ (which was remodelled by King Herod in 20BCE), it was established that God is the paramount leader of the world, the One in His Glory and that God has judged the people of Israel. There was also the issue regarding the destruction of the first Temple. The question remains: How should one relate this destruction to the sins of Israel and how will God lead them into a new situation. Therefore, the question of the restoration of both Jerusalem and the Temple remains very important for Jewish thought.

Although the event was regarded as the consequence of their sins, especially by the prophets, the Jews also understood the implications of the disasters in another way. Reponses to these calamities led to important theological views. Assis (2009:55ff.) explains that family and community were viewed as substitutes for the Temple after its destruction. He refers to the fact that family and community were very important in building up the relation with the people of Israel and God. After the destruction of the Temple in 70AD, Jewish life had to be reestablished. The question was: How to live a new life after the terrible things that happened? Psalms 127 and 133 have important implications for the situation after the calamities of the destruction of the first Temple (Assis, 2009:56). The two Psalms after the Babylonian captivity explain how the community was established after the destruction of the Temple. The Psalms relate to the brotherhood and sisterhood of the community after the destruction. These Psalms regard family as a substitute for the Temple (Assis, 2009:61).

Assis (2009:62) writes:

The Jerusalem Temple held a central position in the relationship between the people of Yehud and their God and its destruction created a major theological challenge for them. How were they to continue the religion and maintain their identity as a people without the Jerusalem Temple? There was an urgent and essential need to discover what could serve as a substitute for the Temple, so long as it remained destroyed and unusable.

Assis (2009:62) then refers again to the fact that the family and the community are temporary alternatives for a Temple and Jerusalem. This is an important aspect. The Temple was destroyed, but the people of Israel found a new way of dealing with it. The Temple was viewed as an earthly pattern of Gods' heavenly kingdom (see Exodus 25: 8-9; 1 Chronicles 28:19; Isaiah 6:1-3) and thus it was hugely significant to Jews. They therefore began to establish a community of faith amidst the challenges they faced. This emphasis on family and a community of faith led to a new relation with God after the destruction. 
Marx (2013:61ff.) refers to the fact that the Jews, after the destruction of the Temple and in modern Judaism, will have to come to grips with the question of how to deal with it, how to live with this reality, and how to create new symbolism in living with this reality. They had to understand this new situation and deal with the memory of the destruction of the Temple. They also had to deal with the future, and how it can be re-imagined. The radical destruction of the Temple caused much stress for the Jewish community. The word of the prophets resonated in the aftermath of the death and the destruction. So many were killed. Houses were destroyed. Land occupied. The relation between God and the Jewish people was still very important (Marx, 2013:76-77):

Paradoxically, the Temple's influence increased following its destruction and its absence is present in the tapestry of Jewish life. In the past, only those who made pilgrimage and entered its gates experienced the Temple. Yet only after its destruction can every Jew symbolically visit the Temple on a regular basis, by studying its laws, praying in its direction, observing the festivals of the Jewish calendar and celebrating life cycle events. The Temple's symbols are part of the life of every Israeli who holds an Israeli identity card and passport, which bears the motif of the Menorah.

One of the consequences of the calamities was that the Jews turned into themselves. Their existence had to be found in their inner being and in their relation with the Torah. They became a close-knit community with a view to keeping their community intact. The debate with the Christians regarding the reasons for the destruction of the Temple led to much misunderstanding.

\section{Christian views of the destruction of the Temple}

The question of how Christians regarded the destruction of the Temple is also important. A few articles refer to these aspects of Christian understanding of the destruction of the Temple. In Christian thought and in the Gospels, the destruction of the Temple is clearly linked to the fact that Jesus foresaw it and cleansed the Temple. Many of these articles regard Jesus' way of dealing with the Temple destruction in this way.

\section{Jesus and the destruction of the Temple}

Köstenberger (2005:205ff.) refers to the fact that the destruction of the Temple can explain how the Fourth Gospel was viewed as indisputable after the destruction in 70AD. The impact is radical and led to a very important event. "The debacle of the war" and "The window of opportunity" for Christians in that emergent Christianity are evident in this respect (Köstenberger, 2005:216). According to Köstenberger (2005:219), the destruction of the Temple radically influenced Jewish life, especially in the diaspora and how they had to regard this terrible situation and refer to Christians in this respect. Köstenberger refers to a Temple motive in light of the destruction of the second Temple. He refers to the fact that the Temple plays an important role in the Fourth Gospel. He also refers to the many aspects of the Fourth Gospel that refer to Jesus and the Temple and the implication of the Temple in this regard. Köstenberger (2005:241) writes:

Doubtless reading of the gospel in this light will result in recovering an important aspect of John's message, intended and highly relevant for his first readers, that, now that the temple had been destroyed, the 
resurrected Jesus was without peer or rival as the new tabernacle, the new temple, and the new centre of worship for a new nation which encompasses all those who are united by faith in Jesus as Messiah.

Brown (1971:LXX) mentions that the Gospel of John had multiple views of Jesus' relation with the Jews. Jesus is regarded as the true Messiah contrary to the beliefs of the Jews. He is the Son of God. John used Old Testament Tabernacle imagery to stress the God, the Logos, exists in human form as a 'God-man'. In the new temple the glorious body of Christ will become the focus of genuine worship for those who accept the Paraclete or Holy Spirit. The Jews also have many different meanings for the term and do not only refer to the Jewish community but often to the leaders who rejected Jesus. Jesus uses "apologetics" and "polemics" in his encounter with the Jews and these must be viewed as an invitation to the Jewish Christians in the diaspora and proclamation against the synagogue. Lastly, the Gospel of John polemicises against Christian heretics. All these aspects have clear implications for life after the destruction, because it professes Jesus as the Saviour and Lord of all and that He must be honoured after the destruction.

Goppelt (1983:68ff.) explains how the concept of the Kingdom of God in the Gospels has implications for life after the destruction. After the crucifixion, new life in the Kingdom is possible by living with Jesus. A totally new reality is possible in the coming of the Kingdom. The world will be totally regenerated. It is crucial that the Kingdom be linked to Jesus as Messiah and Son of God. Jeremias (1975:248) also explains that life with God as King is possible in Jesus, because He makes it possible to see God in Him. This will lead to "blessedness" in Jesus.

Kirk (2012:527) is of the opinion that Jesus' view of the destruction of the fig tree has very important aspects relating to the destruction of the Temple. The cursing of the fig tree is linked to the cleansing and the later destruction of the Temple. The cursing of the fig tree became a metaphor for God's judgement on Israel.

According to Evans (1989:237), Sanders emphasises that Jesus' cleansing of the Temple was not so much a cleansing in the sense of doing a ritual act, but rather a prophecy of the destruction of the Temple that would follow. This would explain Jesus' attitude towards the Temple. Jesus caused a crucially new situation.

A plausible historical context for cleansing must be found. Evans does not accept Sanders' view and mentions that there is no compelling reason to view it as a prophecy for the destruction of the Temple, although the cleansing of the Temple implies a totally new understanding of living before and with God.

Concerning the abomination that causes desolation in Matthew, Mark and Luke, Graham (2015:162ff.) mentions that the early Christians regarded this in light of the destruction of the Temple and as an implication thereof. There are many different opinions for understanding this.

Lambrecht (2013:106) rejects Kirk's view that the prophecy of the destruction has to do with Jesus' cursing the fig tree. He opines that this is not an acceptable way of dealing with the story of the fig tree.

It is obvious that Christians regarded the cursing of the fig tree, the cleansing of the Temple, and the prophecies of the destruction of the Temple in light of God's judgement on Israel for the rejection of Jesus. After the destruction of the Temple, Christians were also persecuted and had 
to find renewed faith in commitment to Jesus. The relation with the Jews was stressful and misunderstood.

Perrin (2015:255ff.) refers to the first very important work of N.T. Wright "Jesus and the victory of God", which regarded Jesus' role in the Gospels as relating to that of a second-Temple prophet. Jesus also referred to the fact that the destruction of the Temple will take place in such a way that it should be linked to what Jesus had done and the implications of Jesus' way of doing. Perrin differs from this view and is of the opinion that the Jesus reference to building up the Temple is more appropriate.

Perrin (2015:275) refers to Wright's view, stating that it is a very important possibility, but that one should not take it for granted. Jesus' resurrection was also to be understood as very important for building up the Temple.

Welzen (2015:1ff.) mentions the emphasis on the Jesus of peace and love, without taking into account that judgement is also part of the Lucan Jesus and that the destruction of the Temple should be viewed as such. Luke does not shy away from judgement, nor from the fact that the Temple will be destroyed and that this has implications for the way in which one views Jesus: not only as the Jesus without violence, but also as the Jesus of repentance and judgement.

According to Joseph (2016), the cleansing of the Temple was an important aspect of Jesus' ministry and could have led to Jesus' execution. Joseph views the Temple incident in light of Jesus' restoration. The future restoration of the Temple of eschatological new birth can refer to Jesus himself. Joseph (2016:95) writes:

The Gospels represent the Temple incident as an eschatological 'cleansing' of the Temple and/or a prophetic demonstration of the Temple's imminent destruction, but these portrayals co-exist in tension with and are overshadowed by the idea that Jesus' sacrificial death replaced the need for Temple sacrifice. The idea that Jesus criticized the practice of violent animal sacrifice was scandalous - to both Jews and Christians - for whom sacrifice served as the central theme of their cultic traditions: the Jesus of the Gospels does not 'abolish' the Temple; he replaces it with his own body and death as the ultimate sacrifice.

\section{Lamentation and destruction}

Moffitt (2006) explains that, in Matthew 27:46, the climax of the crucifixion is linked to Lamentations $2: 15$, leading up to the crucifixion. Lamentations is regarded as very important to understand Jewish life after the destruction of the Temple (Moffitt, 2006:303). Lamentations is linked to the destruction of the Temple (Moffitt, 2006:304). It is also likely that Matthew referred to Lamentations at Jesus' death. Moffitt (2006:309) refers to Lamentations as intertext in Matthew 23 and 27:

By portraying Jesus as a righteous man in ch. 27, Matthew recalls the themes of 23:35-24: 2 . In this way he further employs his earlier allusion to Lamentations in 23:35 to suggest that the shedding of Jesus' blood at the crucifixion becomes the primary reason for the Temple's destruction. It is within this framework that Matthew's account of the crucifixion occurs. With this in mind I propose that Matthew introduces two more 
allusions to Lamentations during his passion account - one in 27:34 and another in 27:39.

Jesus' death is clearly linked to the total destruction of the Temple (Moffitt 2006:316). Moffitt (2006:320) writes:

\begin{abstract}
Yet Matthew's intertextual use of Lamentations, particularly as his appeal to this text both focuses the blame for the shedding of Jesus' righteous blood on the Jewish leaders in Jerusalem and provides a scriptural paradigm for interpreting and explaining the events of 70CE., suggests that one cannot simply assume that Matthew's claims are anti-Jewish. Matthew's appeal to Lamentations makes it far more likely that he envisions himself speaking a prophetic word. In chs. 23 and 27, Matthew engages in intra-Jewish conversation and polemic, patterning his critique of the Jewish religious leadership in Jerusalem on the Jewish prophetic tradition -an interpretive move that bears remarkable resemblance to the one made in the Targum for Lamentations.
\end{abstract}

\title{
Destruction and the love of God
}

Scheffler (2016:92ff.) mentions that the historical Jesus must be viewed as a person of peace and non-violence. The references to many of Jesus' acts in the Gospel sometimes refer to Jesus as radical and violent. This must be re-imagined. Scheffler $(2016: 103,104)$ mentions that Jesus' words concerning violence and the cleansing of the Temple (Scheffler, 2016:106) refer to some kind of violence in Jesus. He did differ from many people (Scheffler, 2016:108). Jesus did not propose violence in the sense of physical violence. Scheffler $(2016: 116)$ concludes that Jesus was against violence in all instances. Scheffler rejects the idea that Jesus' message of love and peace is impractical. He mentions that Jesus' non-violent message must be viewed as ethical and that love for the enemy must be a very important calling for deeds of love. This is not contrary to all conflict (Scheffler, 2016:118), but an existential choice such as taken by Bultmann. He explains that the church must always call for peace according to Jesus' message. The church and the community must start peace projects. The church has a major role to play in bringing people together and in establishing peace. Christians must also get involved and not wait for others.

It should be understood that the destruction of the Temple led to different situations. First, it led to the Jews having to understand their life and their future in a totally new way. Secondly, it led to the Christians' understanding of the end of Judaism with the proclamation of Jesus as the King and Lord of all, so that the church had to renew and understand how to deal with all the aspects in a new way. How would the church understand this after the destruction of the Temple, when many Christians were persecuted, causing them to flee and be persecuted by Roman emperors. The community of the church is all important and should be re-established; the community of the church in community with Christ Jesus as the Lord of the church, the salvation of the church in the community with Christ, but also community among people. Community among Christians has a message for the world based on Missio Dei that, postCOVID-19, the Gospel of Christ must be gloriously proclaimed in all respects to all people so that they may hear that Jesus is Lord and that they may find their salvation in Christ.

\section{Rebuilding after COVID-19}


The COVID-19 pandemic profoundly influenced the way in which the world experiences life and the situation in which people find themselves. The reaction to the pandemic calls for a new understanding of how rebuilding should take place in the future. There are a few challenges. First, the view on the pandemic is important. A scientific and theological understanding of the virus could suggest how rebuilding should take place. Secondly, one should regard the pandemic's influence on societies as a way of viewing future possibilities of new relations after the pandemic. Thirdly, one should regard the medical implications of such an epidemic and how these should be approached in future. Fourthly, the economic implications should be clear, and attention should be paid to the huge disparity in the world as a result of the pandemic.

\section{The church}

After destruction, the church has an important role to play. Theologians and pastors should view this as an opportunity to explain how the future is possible after the pandemic. The church also has a profound influence on society. The suggestion to find new relations, especially as families, is extremely important. After the destruction of the temples, Jewish communities, in particular, had to live in new relations. The church should also empower communities to be in new relations. Medical implications are crucial and the church should stress positive views on vaccines. From an economic point of view, the church should be concerned about the disparity in income after the pandemic and do everything possible to alleviate poverty.

Mpofu (2021:6) draws an important conclusion regarding the church's response to COVID-19. A new way of digital worship and community is now possible:

I proposed the term sacred transversality to describe the creation of new religious meanings at the intersection of emerging narratives generated by digital spaces, which mediate interaction through 'telepresence', embodied in the representations of the sacred available through online systems where users are no longer ordinary believers - but religious participants who have power and freedom to choose when and who they want to associate with.

After the destruction of the Temple in 70CE, the church saw an opportunity to confess Christ as the Saviour. He is the new temple who gave his body to save all, and one should worship Him in this regard. The church took the opportunity to confess Christ after the destruction. It explained God's judgement and confessed Christ and the glory of the grace of God in Him. Although many Christians also suffered during the destruction of the Temple, they regarded it as a sign that Jesus is the true Saviour. Post-COVID-19, the opportunity to confess Christ as Saviour is again very clear. The church should grasp the opportunity to confess anew that Christ is the Lord and one should enter into a relation with Him. This is the future to be sought after the destruction.

Baron and Maponya (2020:5) write:

There seems to be a lack of re-imagination of being the church in South Africa, particularly from those that would for decades envisage the church as being preoccupied with itself. Therefore, the authors argue that for the church to become more 'prophetic', church members need to be encouraged to 're-imagine' the nature of the church. When this will be done, the church should subsequently move to its process of reimagination and structure itself in different shapes and forms. 


\section{The community}

Both the Jewish and the Christian community had to adapt after the destruction of the Temple. They took different approaches to the situation. The Jews had to renew their religion and accept that the centre of their worship was destroyed. This led to a hardening of their faith. The relation to the Christians in the years after the destruction of the Temple deteriorated. The Christians had to establish their faith in difficult circumstances. To them, Jesus' words came true. His crucifixion was related to the judgement of God on those who crucified Him. The community of Christians, often persecuted by Jews and non-believers, had to relate to the challenges of establishing their faith. They overcame their hardship by yielding to Jesus as Lord. The new community of the church was established.

\section{Post-COVID-19}

The COVID-19 pandemic will have radical consequences. Some people and some countries will never fully recover from it. There will be a time after COVID-19 to build up the community again. The church can play an immense role in this, by grasping the opportunity to be totally committed to Jesus Christ, to confess, glorify and serve Him in the world so that people can experience new possibilities and new life. Through the Holy Spirit in Christ, the new creation is real in the church as the children of God. The church should live out the new relation with God and the world in such a way that people will find new hope again.

\section{Conclusion}

There is no doubt that the destruction of the Temple influenced the lives of both Jews and Christians considerably. The Jews reverted to the Torah and family life. Covid-19 led to terrible poverty and want all over the world. Many people are still mourning loved ones they have lost. Not only the elderly but also children died. The destruction of the temple had immense implications for the Jewish people. They had to understand it to begin a new life. Jews and Christians saw it as Gods judgement but had different responses to it. For the Jews a new commitment to community was necessary. Christians saw it in the light of Jesus' death and resurrection. The Christians saw an opportunity to proclaim Jesus as Lord and Saviour. The new Temple was now his resurrected body. All should honour him. After COVID-19, the church should again be constructed in the faith in Jesus the Lord. The believers should be prepared to confess Him anew as Lord and be prepared to be involved in the community, in order to bring about new life. The church should proclaim unconditionally that Jesus is the One that can give hope to the world because his body is the new temple of God and that the church in Him is also a new temple of God.

\section{References}

Assis, E. (2009). 'Family and community as substitutes for the temple after its destruction: New readings in Psalms 127 and 133', Ephemerides Theologicae Lovanienses, 85(1),55-62. [Available at: https://search-ebscohost-com.ufs.idm.oclc.org/login.aspx?direct=true\&db=rfh $\& A N=A T L A 0001738964 \&$ site=ehost-live\&scope=site] (Accessed: 11 October 2021).

Baron, E. \& Maponya, M.S. (2020). 'The recovery of the prophetic voice of the church: The adoption of a 'missional church' imagination', Verbum et Ecclesia, 41(1), a2077. https://doi.org/10.4102/ ve.v41i1.2077

Bright, J. (1977). A history of Israel. (Revised edition), London: SCM. (Old Testament Library). 
Brown, R.E. (1971). The Gospel according to John (I-XII), London: Chapman. (The Anchor Bible, Vol. 29).

Bruce, F.F. (1969). Israel and the nations, Exeter: Paternoster.

De Silva, D.A. (2004). An introduction to the New Testament contexts, methods, and ministry formation, Downers Grove, ILL: IVP Academic.

Dillard, R.B. (1987). 2 Chronicles. Vol. 15. Dallas: Word Incorporated. (Word Biblical Commentary).

Evans, C.A. (1989). 'Jesus' action in the temple: Cleansing or portent of destruction?', The Catholic Biblical Quarterly, 51(2), 237-270. [Available at: https://search-ebscohostcom.ufs.idm.oclc.org/login.aspx?direct=true\&db=rfh\&AN=ATLA0000813663\&site=ehostlive\&scope=site] (Accessed: 11 October 2021).

Goppelt, L. (1983). The ministry of Jesus in its theological significance, (Translated by J. Alsup). Grand Rapids, MI: Eerdmans. (Theology of the New Testament, Vol. 1).

Graham, D. (2015). 'Early Christian understandings of the "abomination that causes desolation"', The Reformed Theological Review 74(3), 162-175. [Available at: https://searchebscohostcom.ufs.idm.oclc.org/login.aspx?direct=true\&db=rfh\&AN=ATLAn3834940\&site=ehostlive\&scope=site] (Accessed: 11 October 2021).

Harrison, R.K. (1971). Old Testament times, London: Inter-varsity.

Hobbs, T.R. (1985). 2 Kings. Vol. 13, Dallas, TX: Word, Incorporated, (Word Biblical Commentary).

Holladay, W.L. (1989). Jeremiah 2. A commentary on the book of the prophet Jeremiah. Chapters 26-52, Philadelphia, PA: Fortress. (Hermeneia).

Jeremias, J. (1975). New Testament theology, Vol. 1, London: SCM.

Joseph, S.J. (2016). 'Jesus and the Temple incident: A new proposal', Journal for the Study of the Historical Jesus 14(1), 71-95. [Available at: https://search-ebscohostcom.ufs.idm.oclc.org/login.aspx?direct=true\&db=rfh\&AN=ATLAiG0V160912001047\&site=ehostlive\&scope=site] (Accessed: 11 October 2021).

Kirk, J.R.D. (2012). 'Time for figs, temple destruction, and houses of prayer in Mark 11:12-25', The Catholic Biblical Quarterly, 74(3), 509-527. [Available at: https://search-ebscohostcom.ufs.idm.oclc.org/login.aspx?direct=true\&db=rfh\&AN=ATLA0001904686\&site=ehostlive\&scope=site] (Accessed on 11 October 2021).

Köstenberger, A.J. (2005). 'The destruction of the second temple and the composition of the fourth gospel', Trinity Journa, 26(2), 205-242. [Available at: https://search-ebscohostcom.ufs.idm.oclc.org/login.aspx?direct=true\&db=rfh\&AN=ATLA0001626352\&site=ehostlive\&scope=site] (Accessed: 11 October 2021).

Lambrecht, J. (2013). 'The cleansing of the temple (Mark 11,15-19)', Ephemerides Theologicae Lovanienses 89(1), 103-106. [Available at: https://search-ebscohostcom.ufs.idm.oclc.org/login.aspx?direct=true\&db=rfh\&AN=ATLA0001953790\&site=ehostlive\&scope=site] (Accessed: 11 October 2021).

Marx, D. (2013). 'The missing temple: The status of the temple in Jewish culture following its destruction', European Judaism 46(2), 61-78. Available at: https://search-ebscohost- 
com.ufs.idm.oclc.org/login.aspx?direct=true\&db=rfh\&AN=ATLA0001957696\&site=ehostlive\&scope=site (Accessed: 11 October 2021).

Moffitt, D.M. (2006). 'Righteous bloodshed, Matthew's passion narrative, and the Temple's destruction: Lamentations as a Matthean intertext', Journal of Biblical Literature 125(2), 299320. [Available at: https://search-ebscohost-com.ufs.idm.oclc.org/login.aspx?direct=true\&db=rfh \&AN=ATLA0001524078\&site=ehost-live\&scope=site] (Accessed: 11 October 2021).

Mpofu, B. (2021). 'Transversal modes of being a missional church in the digital context of COVID-19', HTS Teologiese Studies/Theological Studies, 77(4), a6341. [Available at https://doi.org/ 10.4102/hts.v77i4.6341]

Patterson, R.D. \& Hermann, J.A. (1988). “1, 2 Kings”. In: The Expositor's Bible Commentary 1 \& 2 Kings, 1 \& 2 Chronicles, Ezra, Nehemiah, Esther, Job, edited by F.E. Gaebelein, 4:296, Grand Rapids, Ml: Zondervan Publishing House.

Payne, J.B. (1988). “1, 2 Chronicles”. In The Expositor's Bible Commentary: 1 \& 2 Kings, 1 \& 2 Chronicles, Ezra, Nehemiah, Esther, Job, edited by F.E. Gaebelein, 4, 558-559, Grand Rapids, MI: Zondervan Publishing House.

Perrin, N. (2015). 'From one stone to the next: Messiahship and temple in N.T. Wright's Jesus and the victory of God', Journal for the Study of the Historical Jesus, 13(2-3), 255-275. [Available at: https://search-ebscohost-com.ufs.idm.oclc.org/login.aspx?direct=true\&db=rfh\&AN =ATLAn3894109\&site=ehost-live\&scope=site] (Accessed: 11 October 2021).

Scheffler, E. (2016). 'Vyandsliefde of geweld: Oor die politiek van die historiese Jesus', Acta Theologica, 36(2), pp. 92-124. Available at: https://search-ebscohost-com.ufs.idm.oclc.org/login. aspx?direct=true\&db=rfh\&AN=ATLAiFZU171218003585\&site=ehost-live \&scope=site (Accessed: 11 October 2021).

Stone, M.E. (1981). 'Reactions to destructions of the second Temple: Theology, perception and conversion', Journal for the Study of Judaism in the Persian, Hellenistic and Roman Period, 12(2), pp. 195-204. [Available at: https://search-ebscohost-com.ufs.idm.oclc.org/login.aspx?

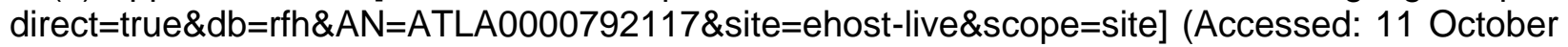
2021).

Volkmar, F. (2003). A continental commentary: 1 \& 2 Kings, Translated by A. Hagedorn. Minneapolis, MN: Fortress Press.

Weiser, A. (1972). Introduction to the Old Testament, London: Darton, Longman \& Todd.

Welzen, H. (2015). 'Vrede en oordeel in het evangelie volgens Lucas', Hervormde Teologiese Studies, 71(1), 1-11. [Available at: https://search-ebscohost-com.ufs.idm.oclc.org/login.aspx ?direct=true \&db=rfh\&AN=ATLAn3819495\&site=ehost-live\&scope=site] (Accessed: 11 October 2021). 